
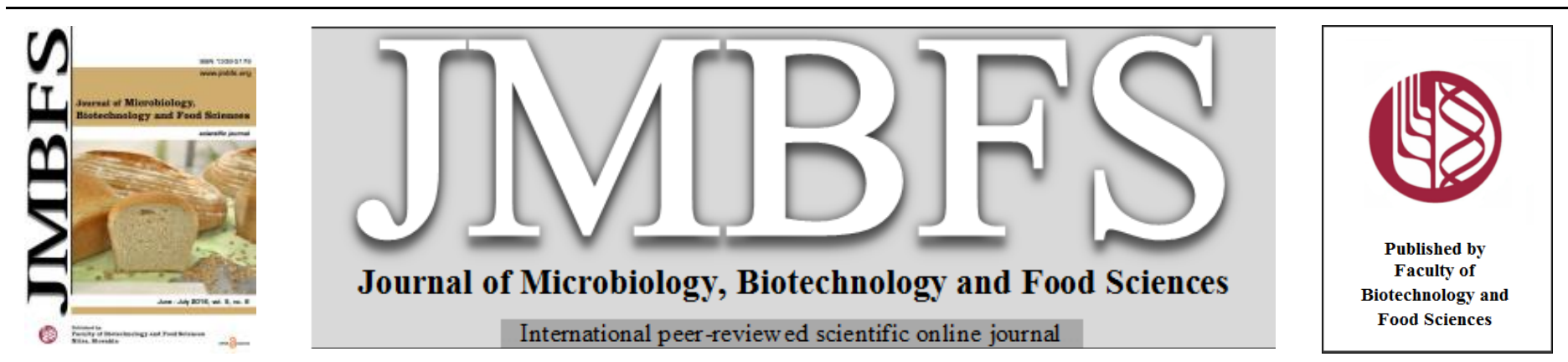

\title{
INFLUENCE OF MAGNETIC FIELD STIMULATION ON THE GROWTH AND BIOCHEMICAL PARAMETERS IN PHASEOLUS VULGARIS L.
}

\section{Mroczek-Zdyrska ${ }^{1}$, L. Tryniecki $^{l}$, K. Kornarzyński ${ }^{2}$, S. Pietruszewski ${ }^{2}$, M. Gagos ${ }^{1}$}

\author{
Address(es): dr Magdalena Mroczek-Zdyrska, \\ ${ }^{1}$ Department of Cell Biology, Maria-Curie Sklodowska University, Akademicka Street 19, 20-033 Lublin, Poland. \\ ${ }^{2}$ Department of Physics, University of Agriculture, Akademicka Street 13, 20-033 Lublin, Poland.
}

*Corresponding author: magdalena.mroczek@ poczta.umcs.lublin.pl

doi: 10.15414/jmbfs.2016.5.6.548-551

\section{ARTICLE INFO}

Received 12. 1. 2015

Revised 12. 11. 2015

Accepted 13. 2. 2016

Published 1. 6. 2016

Regular article

open $\odot$ access

\begin{abstract}
Plant response to magnetic field stimulation (MFS) is varied and dependent on many factors such as the intensity, time of exposition, or application form. It is known that high intensity MFS inhibits the growth and development of plants. However, weak MF stimulates many processes in plant cells. This study reports the effects of 130-mT magnetic field stimulation (MFS) on the growth and selected biochemical parameters in the common bean (Phaseolus vulgaris L.) in laboratory conditions. Our results indicated that the stimulation of plants by a weak permanent magnetic field $(130 \mathrm{mT})$ increased mitotic activity in meristematic cells of the common bean $(P$. vulgaris L.). There was no influence of the 130-mT MFS on the development of aboveground plant parts; however, there was a marked increase in GPOX activity in the leaves after 130-mT magnetic field stimulation.
\end{abstract}

Keywords: Bean, magnetic field, growth, assimilation pigment, antioxidant enzyme

\section{INTRODUCTION}

Both magnetic and electromagnetic field influence the functioning of biological organisms. The literature describes the effects of electromagnetic field on seed germination (Aksyonov et al., 2001) or antimicrobial activity (Akinyele $\boldsymbol{e t} \boldsymbol{a l}$. 2012). Despite the extensive literature on the effects of magnetic field stimulation (MFS) on plants (Pietruszewski et al., 2001; Belyavskaya, 2004; Çelik et al., 2009; Muszyński et al., 2009; Jouni et al., 2012), recognition and understanding of the mechanisms of action of the magnetic field on the plant organism is still a challenge for researchers. Identification of the mechanism of magnetic field stimulation may be a key in regulating the biological activity of plants (Cakmak et al., 2012). It has been well documented that magnetically treated water (Alkassab and Albach, 2014) or magnetic field stimulation exerts an effect on plants (Belyavskaya, 2004; Çelik et al., 2009; Muszyński et al., 2009; Jouni et al., 2012). However, the response of plants to magnetic field stimulation depends on the species, dose, or exposure time (Pietruszewski et al., 2001). The optima magnetic field stimulates plant growth and development or seed germination (Pietruszewski et al., 2001). It was observed that weak magnetic field stimulation had a beneficial effect on seed germination in radish (Novitskaya $\boldsymbol{e t}$ al., 2001), root formation in wheat (Aksyonov et al., 2001), or formation of somatic embryos in cultures of alfalfa (Medicago sativa L.) (Dijak et al., 1986) Moreover, studies on the meristematic cells of pea have shown that the magnetic field has an influence on metabolism and cellular division (Belyavskaya et al. 1992). However, Lebedev et al. (1977) showed a decrease in the fresh and dry weight of shoots and roots in barley seedlings. Moreover, the function of antioxidant enzymes (SOD and CAT) in Glycine max (L.) seedlings was intensified due to treatment with the magnetic field (Çelik et al., 2009)

Nowadays, the results obtained by researchers on the magnetic field stimulation are particularly promising and important. This is due to the huge interest in the environment-friendly technology and the possibility of obtaining increased yields without the use of fertilizers.

The bean (Phaseolus vulgaris L.) is often used for laboratory testing due to its rapid growth, a short period of vegetation, and relatively low cultivation requirements. The bean is an important legume constituting a major source of proteins, fibre, prebiotics, vitamin B, and micronutrients for humans worldwide. In addition, some species of legumes are used as animal fodder (Câmara et al., 2013). These properties have contributed to the selection of these plants for this study.

The objective of our study was to investigate the influence of weak permanen magnetic field stimulation $(130 \mathrm{mT})$ on the growth and selected biochemical parameters of the common bean (Phaseolus vulgaris L.).

\section{MATERIAL AND METHODS}

Seeds (20 seeds per 1 replication) of the common bean (Phaseolus vulgaris L.) were sown in seed trays on filter paper moistened with distilled water. The plant material was divided into two groups: the control (C) and experimental group (MF). Seeds from the control group (C) were growing in a natural magnetic field while the seeds of the test group (MF) were grown during the experimental period (14 days) in the presence of $130-\mathrm{mT}$ permanent magnetic field (MF) perpendicular to the plants. Based on previous studies, we selected the induction of $130 \mathrm{mT}$, which gives the best results, for the magnetic field (Kornarzyński $\boldsymbol{e}$ al., 2004). The seeds germinated at $20 \pm 2^{\circ} \mathrm{C}$, at a $12 / 12 \mathrm{~h}$ photoperiod and an illumination of 300 lux in the vegetation chamber for 14 days. After this time, the plant material was used to the analyses. Plant breeding was conducted in the Department of Physics, University of Life Sciences in Lublin.

\section{The biometric parameters}

After 14 days of the experiment, the basic growth parameters: fresh weight, average length of roots and shoots, and the average length and width of leaves were analysed. Plant individual average length of roots and the aboveground parts of plants was measured with $0.1 \mathrm{~cm}$ precision. The fresh weight $(\mathrm{FW})$ of seedling samples was measured with $10^{-5} \mathrm{~g}$ accuracy. The biometric measurements were performed in triplicate for selected 10 plants at the same physiological age.

\section{Cell division}

To study the mitotic activity, 14-day-old root meristems were fixed for $24 \mathrm{~h}$ in AA $\left(92 \% \mathrm{EtOH}\right.$ and $\left.\mathrm{CH}_{3} \mathrm{COOH}, 3: 1\right)$ and stained in $0.5 \%$ acetocarmine. After staining, the plant material was rinsed with $\mathrm{dH}_{2} \mathrm{O}$ and macerated for 10 minutes in a solution: $\mathrm{HCl}$ (conc.) : $96 \% \mathrm{EtOH}(1: 1)$. The macerated tissues were placed in $\mathrm{dH}_{2} \mathrm{O}$ for 10 minutes and then in $45 \%$ acetic acid for 10 minutes (Clark 1981). The mitotic index (MI) was calculated as the percentage of proliferating cells among 1000 cells. For the analysis, a Leica DM 4000 B microscope was used.

\section{The biochemical assays}

The biochemical analyses were carried out on day 14 of the experiment and all measurements were performed in triplicate. 


\section{Measurement of assimilation pigments}

The level of chlorophyll a (chl a), chlorophyll b (chl b), chlorophyll a+b (chl $\mathrm{a}+\mathrm{b}$ ), and carotenoids (car) was determined by the Lichtenthaler and Wellburn method (1983). Leaf samples $(0.5 \mathrm{~g})$ were homogenized in $5 \mathrm{ml}$ of $80 \%$ acetone chilled to $4{ }^{\circ} \mathrm{C}$. The homogenate was centrifuged and the precipitate was washed with cold acetone until complete chlorophyll extraction. The extract was supplemented with cold $80 \%$ acetone to $25 \mathrm{ml}$. The absorbance of the supernatant was read at wavelengths of $663 \mathrm{~nm}, 645 \mathrm{~nm}, 652 \mathrm{~nm}$, and $470 \mathrm{~nm}$ in an Agilent Cary $60 \mathrm{UV}-\mathrm{Vis}$ spectrophotometer. The contents of pigments were calculated according to Bruinsma (1963). The extract was diluted with acetone and the absorption spectra were recorded in the range of 800 to $200 \mathrm{~nm}$ using the Agilent Cary $60 \mathrm{UV}-\mathrm{V}$ is spectrophotometer.

\section{Determination of the protein content}

The protein content in the plant material (roots, shoots, and leaves) was determined according to Bradford (1976) using BSA as a standard. The measurement was performed after $15 \mathrm{~min}$. of adding the dye concentrate (BioRad Protein Assay) at a wavelength $\lambda=595 \pm 10 \mathrm{~nm}$ on the Agilent Cary $60 \mathrm{UV}$ Vis spectrophotometer.

\section{Determination of guaiacol peroxidase activity (GPOX)}

The measurement of guaiacol peroxidase activity GPOX (EC 1.11.1.70) was performed according to Velikova et al. (2000). Frozen plant tissues (roots, shoots, and leaves) $(0.5 \mathrm{~g})$ were transferred to a cooled mortar and homogenized with $5 \mathrm{ml}$ of $50 \mathrm{mM}$ phosphate buffer $\mathrm{pH} 7.0$ with $1 \mathrm{mM}$ EDTA and 1\% PVPP. The material was centrifuged at $15.000 \mathrm{rpm}$ at $4^{\circ} \mathrm{C}$ for $20 \mathrm{~min}$. in an MPW 350-R centrifuge. The reaction mixture contained $2750 \mathrm{ml}$ of $1 \%$ guaiacol in $50 \mathrm{mM}$ phosphate buffer at $\mathrm{pH} 7$ and $100 \mathrm{ml}$ supernatant. The reaction was initiated by addition of $150 \mu \mathrm{l} 100-\mathrm{mM} \mathrm{H}_{2} \mathrm{O}_{2}$ to the reaction mixture. The absorbance was read at $470 \mathrm{~nm}$ on the Agilent Cary $60 \mathrm{UV}-\mathrm{Vis}$ spectrophotometer. The specific activity of the enzyme was expressed in $\mathrm{mM} \cdot \mathrm{min}^{-1} \cdot \mathrm{mg}^{-1}$ protein.

\section{Statistical analysis}

The statistical analysis was performed using one-way ANOVA and Tukey's pos hoc analysis for determination interaction significance at $\mathrm{p}<0.05$. The results were expressed as mean values \pm standard deviation (SD).

\section{RESULTS}

The analysis of root growth of common bean (Phaseolus vulgaris L.) showed that the average length of the control roots was $16.72 \mathrm{~cm}$ and that of the MFstimulated plants was $16.80 \mathrm{~cm}$ after 14 days of the experiment. There were no significant differences between these groups. Moreover, no significant influence
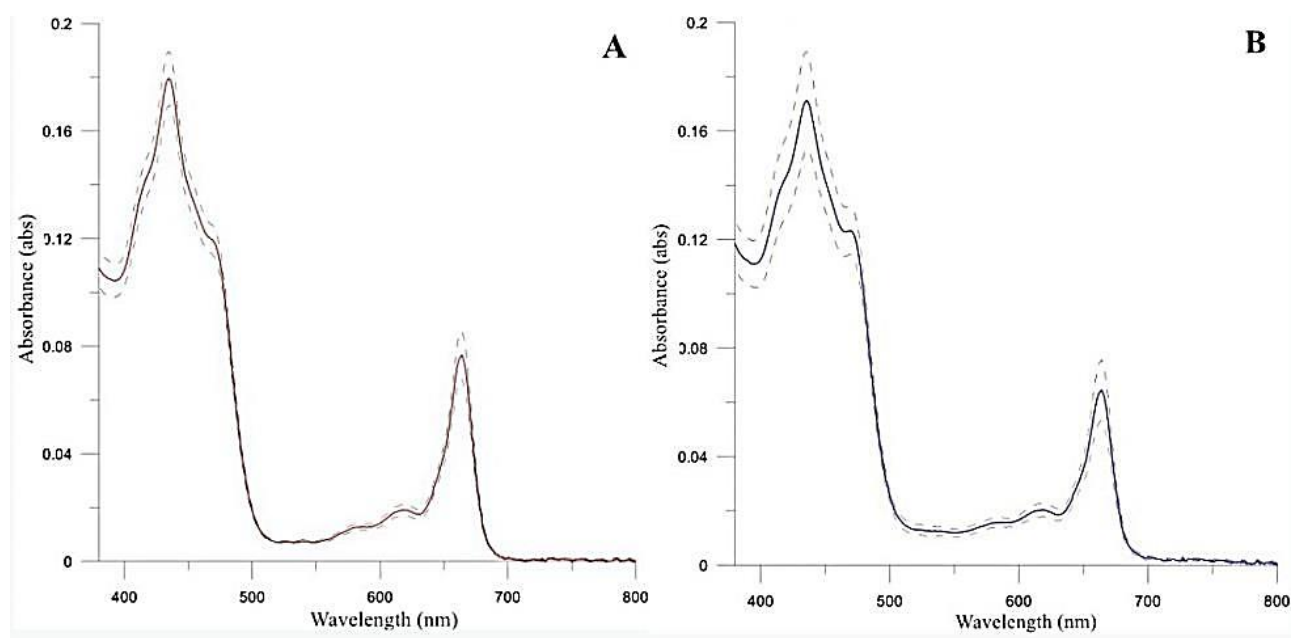

Figure 1 The assimilation pigment absorption spectra in bean (Phaseolus vulgaris L.) leaves. A - control conditions and $\mathrm{B}-$ in the presence of the 130-mT magnetic field (MF).

The measurement of the assimilation pigment content in the leaves (chl a, chl b, $\mathrm{chl} \mathrm{a}+\mathrm{b}$, carotenoids) was performed on day 14 of the experiment. In the leaves of the common bean $(P$. vulgaris L.), the pigment content of the control was 0.21 mg. $\mathrm{g}^{-1} \mathrm{FW}$ (chl a), $0.09 \mathrm{mg} \cdot \mathrm{g}^{-1} \mathrm{FW}$ (chl b), and $0.33 \mathrm{mg} \cdot \mathrm{g}^{-1} \mathrm{FW}$ (chl a+b). The pigment content in the MF-stimulated leaves was $0.16 \mathrm{mg}^{-1} \mathrm{~g}^{-1} \mathrm{FW}$ (chl a), 0.08 mg. $\mathrm{g}^{-1} \mathrm{FW}$ (chl b), and $0.26 \mathrm{mg} \cdot \mathrm{g}^{-1} \mathrm{FW}(\mathrm{chl} \mathrm{a}+\mathrm{b})$. We noted that MFS did not influence significantly the chlorophyll content (Table 3). Similarly, the carotenoid content in the bean leaves was $0.13 \mathrm{mg} . \mathrm{g}^{-1} \mathrm{FW}$ in the control and 0.12 mg. $\mathrm{g}^{-1} \mathrm{FW}$ in the MF-stimulated leaves and this indicated that the carotenoid content in bean leaves exposed to MF remained at the control level (Table 3). of the 130-mT MF on the shoot and leaf growth was observed. The average shoot length and the average length and width of leaves of the MF-stimulated plants persisted at the control level. Additionally, the fresh weight (FW) of the MFstimulated plants remained at the control level and there were no statistically significant differences between the analysed plant groups (Table 1).

Table 1 Average length $[\mathrm{cm}]$ of the primary organs, average length and width $[\mathrm{cm}]$ of the leaves, and average weight $[\mathrm{g}]$ of bean seedlings (Phaseolus vulgaris L.).

\begin{tabular}{|c|c|c|c|c|c|}
\hline Description & $\begin{array}{l}\text { Roots } \\
{[\mathrm{cm}]}\end{array}$ & $\begin{array}{l}\text { Shoots } \\
{[\mathrm{cm}]}\end{array}$ & $\begin{array}{l}\text { Leaf length } \\
{[\mathrm{cm}]}\end{array}$ & $\begin{array}{l}\text { Leaf width } \\
{[\mathrm{cm}]}\end{array}$ & $\begin{array}{c}\text { Seedling } \\
\text { weight } \\
{[\mathrm{g}]}\end{array}$ \\
\hline C & $\begin{array}{c}16.72 \pm 1.40 \\
a\end{array}$ & $\begin{array}{c}25.63 \pm 6.48 \\
a\end{array}$ & $\begin{array}{c}2.02 \pm 0.17 \\
a\end{array}$ & $\begin{array}{c}1.29 \pm 0.30 \\
\mathrm{a}\end{array}$ & $\begin{array}{c}1.54 \pm 0.43 \\
\mathrm{a}\end{array}$ \\
\hline MF & $\begin{array}{c}16.80 \pm 2.38 \\
\mathrm{a}\end{array}$ & $\begin{array}{c}25.44 \pm 1.83 \\
\mathrm{a}\end{array}$ & $\begin{array}{c}1.87 \pm 0.22 \\
\mathrm{a}\end{array}$ & $\begin{array}{c}1.30 \pm 0.19 \\
\mathrm{a}\end{array}$ & $\begin{array}{c}1.58 \pm 0.26 \\
\mathrm{a}\end{array}$ \\
\hline
\end{tabular}

$30, p>0.05$. Numbers in columns marked with the same letters do not differ significantly.

On the contrary, the study showed that in bean plants (P. vulgaris L.) the stimulation with the magnetic field had a beneficial effect on the mitotic activity in the root meristem cells. The mitotic index (MI) value was $36.33 \%$ in the control roots, while the mitotic activity in the MF-stimulated roots was $57.8 \%$, and this was a statistically significant increase by $59 \%$ in comparison to the control level. The average number of cells in the different phases of mitosis in the control plants was 64 in the prophase, 29 in the metaphase, 23 in the anaphase, and 247 in the telophase. In the MF-stimulated root meristems of bean plants, the following values were noted: 83 in the prophase, 35 in the metaphase, 17 in the anaphase, and 443 in the telophase. Importantly, a beneficial effect of MF on the number of cells was observed in the metaphase and telophase stages, and the numbers were increased by $23 \%$ and $79 \%$, respectively, in relation to the control (Table 2).

Table 2 Mitotic index (MI) [\%] and the number of cells in the different phases of mitosis in root meristems of bean (Phaseolus vulgaris L.).

\begin{tabular}{|c|c|c|c|c|c|}
\hline Description & $\begin{array}{l}\text { MI } \\
{[\%]}\end{array}$ & Prophase & Metaphase & Anaphase & Telophase \\
\hline $\mathrm{C}$ & $\begin{array}{c}36.33 \pm \\
3.72 \mathrm{a}\end{array}$ & $\begin{array}{c}64.00 \pm \\
6.39 \mathrm{a}\end{array}$ & $\begin{array}{l}28.67 \pm \\
3.87 \mathrm{a}\end{array}$ & $\begin{array}{c}23.33 \pm 4.47 \\
\mathrm{a}\end{array}$ & $\begin{array}{c}247.33 \pm 26.03 \\
\mathrm{a}\end{array}$ \\
\hline MF & $\begin{array}{c}57.80 \pm \\
1.31 \mathrm{~b} \\
\end{array}$ & $\begin{array}{c}82.67 \pm \\
6.43 \mathrm{a} \\
\end{array}$ & $\begin{array}{c}35.33 \pm \\
3.15 \mathrm{~b} \\
\end{array}$ & $\begin{array}{c}16.67 \pm 5.03 \\
\mathrm{a} \\
\end{array}$ & $\begin{array}{c}443.33 \pm 9.45 \\
b\end{array}$ \\
\hline
\end{tabular}

Continuous measurements of the chlorophyll absorption spectrum were also performed. The highest absorbance was in the ranges of 500 to $400 \mathrm{~nm}$ and 700 to $600 \mathrm{~nm}$ (Fig. 1).
Table 3 The chl a, chl b, chl a+b and carotenoid content $\left[\mathrm{mg} \cdot \mathrm{g}^{-1} \mathrm{FW}\right]$ in leaves of bean (Phaseolus vulgaris L.).

\begin{tabular}{lcccc} 
Description & Chl a & Chl b & Chl a+b & Carotenoids \\
\cline { 2 - 5 } & $0.21 \pm 0.05 \mathrm{a}$ & $0.09 \pm 0.01 \mathrm{a}$ & $0.33 \pm 0.10 \mathrm{a}$ & $0.13 \pm 0.01 \mathrm{a}$ \\
$\mathrm{MF}$ & $0.16 \pm 0.03 \mathrm{a}$ & $0.08 \pm 0.01 \mathrm{a}$ & $0.26 \pm 0.04 \mathrm{a}$ & $0.12 \pm 0.01 \mathrm{a}$ \\
\hline
\end{tabular}

Legend: $\mathrm{C}$ - control conditions, MF - 130-mT magnetic field stimulation. Mean \pm SD, $\mathrm{n}=3$, p> 0.05 . Numbers in columns marked with the same letters do not differ significantly. 
Additionally, the effect of MFS on guaiacol peroxidase activity (GPOX) in the roots, shoots, and leaves of the common bean $(P$. vulgaris L.) plants was analysed. The experiment showed that GPOX activity in the bean roots was 17.1 U.mg ${ }^{-1}$ protein in the control and $20.67 \mathrm{U}^{-m^{-1}}$ protein in the MF-stimulated plants and there were no statistically significant differences between these groups (Fig. 2).

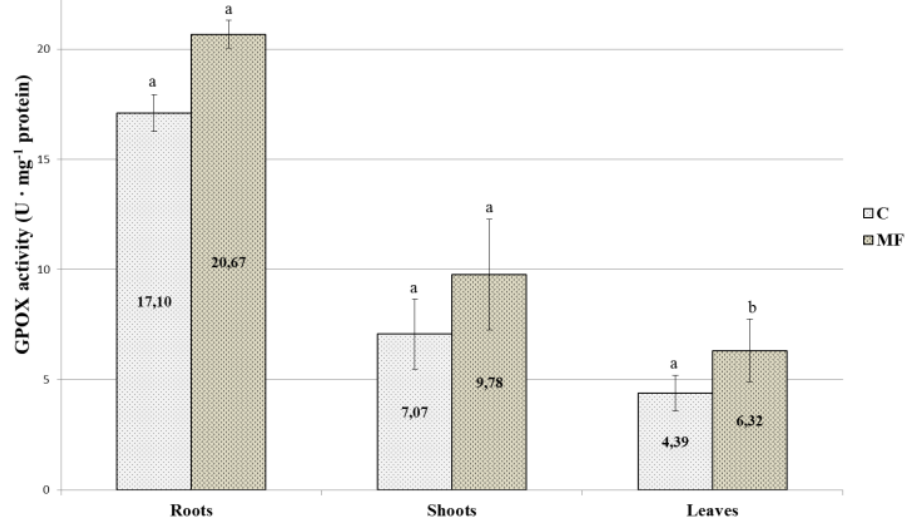

Figure 2 Guaiacol peroxidase activity (GPOX) in bean (Phaseolus vulgaris L.) organs. C - control conditions and MF - 130-mT magnetic field stimulation. Mean $\pm \mathrm{SD}, \mathrm{n}=3, \mathrm{p}>0.05$. Numbers in columns marked with the same letters do not differ significantly.

Similarly, there was no significant influence of MFS on the GPOX activity in the shoots. The study showed that the GPOX activity in the shoots of the control was 7.07 U.mg ${ }^{-1}$ protein and in the MF-stimulated plant $9.78 \mathrm{U} \cdot \mathrm{mg}^{-1}$ protein However, the leaves of the bean plants appeared to be highly sensitive to the 130mT MF stimulation. The activity of GPOX in the control leaves was $4.39{\mathrm{U} . \mathrm{mg}^{-1}}^{-1}$ protein, and $6.32 \mathrm{U}_{\mathrm{mg}}{ }^{-1}$ protein in the leaves exposed to $130 \mathrm{mT} \mathrm{MF}$. A statistically significant increase (by 44\%) in the activity of GPOX was observed in the bean leaves after stimulation with $130 \mathrm{mT}$ MF (Fig. 2).

\section{DISCUSSION}

Magnetic field stimulation (MFS) of plants is one of environmental-friendly techniques used to improve crop yields and seed germination and the results obtained are promising (Pietruszewski and Kania, 2010; Cakmak et al., 2012; Jouni et al., 2012). In this paper, the influence of permanent magnetic field stimulation (130 mT MF) on the growth and development of the common bean (Phaseolus vulgaris L.) was studied. In our experiment, there was no effect of the MF stimulation on the root growth of the common bean. However, Vashisth and Nagarajan (2009) found that 50-mT magnetic field stimulation led to a $42.4 \%$ increase in root length of sunflower. Nagy et al. (2005) also observed a 70\% increase in the sunflower root length after MF stimulation in $0.01 \mathrm{~Hz}-20 \mathrm{kHz}$ and induction of $400 \mu \mathrm{T}$. Moreover, in Lens culinaris, a permanent magnetic field $(120 \mathrm{mT}, 10 \mathrm{~min}$.) increased the root length by $58.96 \%$ (Shabrangi and Majd, 2009). On the other hand, the results of this study showed that the 130-mT MF stimulation had a beneficial effect on cell mitotic activity in common bean $(P$. vulgaris L.) root meristems, and the mitotic index (MI) increased by $59 \%$. Similar results were obtained by Răcuciu (2011), who observed a 3-fold increase in the number of dividing root cells after $12 \mathrm{~h}$ stimulation of maize (Zea mays) with a 10-mT and $50 \mathrm{~Hz}$ magnetic field. Similarly, Shabrangi et al. (2011) observed a $3 \%$ increase in the mitotic activity in meristematic cells after 4-h exposure of maize (Zea mays) to MF stimulation $(60 \mathrm{~Hz}, 3 \mathrm{mT})$. In our study, an increase in the number of cells in the metaphase or telophase stages by $23 \%$ and $79 \%$, respectively, was also observed in bean plants exposed to 130 -mT MFS Răcuciu (2011) and Fomicheva et al. (1992) suggest that the increase in the mitotic activity of root meristems exposed to the magnetic field is caused by prolongation of the duration time of the different phases in the cell cycle and by the number of cells in the different stages of mitosis. This is in agreement with Fomicheva et al. (1992), who also noted a prolonged time of the G1 and G2 phases in Linum usitatissimum L. by $51 \%$ and $33 \%$, respectively.

We also studied the influence of 130-mT MF stimulation on the growth and development of the aboveground plant parts. We noted that 130 mT MFS did not significantly influence the growth of shoots and leaves or fresh weight in bean plants. However, Bilalis et al. (2013) reported a $42 \%$ and $31 \%$ increase in leaf area in cotton (Gossypium hirsutum L. cv. Campo) after stimulation with a magnetic field of $3 \mathrm{~Hz}$ and $12.5-\mathrm{mT}$ induction after 35 and 45 days, respectively. Moreover, Yaycili and Alikamanoglu (2005) observed an increase in the number of leaves by $36 \%$ in Paulownia tomentosa and by $40 \%$ in Paulownia fortunei after MF stimulation (2.9 mT to $4.9 \mathrm{mT}$ ). In turn, Dardeniz et al. (2006) obtained a $17 \%$ increase in shoot length of grapes (Vitis vinifera) after stimulation with $50 \mathrm{~Hz}$ and $0.15 \mathrm{mT} \mathrm{MF}$.
To know better the molecular mechanisms involved in the plant growth processes after MF stimulation, spectrophotometric measurements of selected physiological and biochemical processes (photosynthesis pigment content or GPOX activity) were carried out. Photosynthesis is the main metabolic process in plant growth and development and thus very sensitive to environmental changes. The differences in chlorophyll content are often observed after treatment with various environmental factors (Velikova et al., 2000). In the present study, we indicated that there was no significant effect of the 130-mT MFS on the assimilation pigment content in bean (Phaseolus vulgaris L.). The effect of MFS on the assimilation pigment content is unclear. Atak et al. (2007) showed that stimulation of soybean (Glycine $\max \mathrm{L}$.) with the magnetic field $(2.9 \mathrm{mT}$ to 4.6 mT) decreased the content of chl a, chl b, and chl a+b by $16 \%, 14 \%$, and $14 \%$, respectively. In contrast, the change in the exposure time resulted in an increase in the assimilation pigment content by $21 \%$ (chl a), 13\% (chl b), and $18 \%$ (chl a+b). Similarly, Răcuciu et al. (2008) noted that permanent magnetic field stimulation $(50 \mathrm{mT})$ for 14 days contributed to a $3 \%$ increase in the content of ch $\mathrm{a}+\mathrm{b}$ in maize (Zea mays), but 100 mT MFS decreased the chl $\mathrm{a}+\mathrm{b}$ content by 4\%. Furthermore, Muszyński et al. (2009) noted that chlorophyll levels in Triticum durum seedlings were significantly modified by extremely low frequency magnetic field ( $\mathrm{f}=50 \mathrm{~Hz}, \mathrm{~B}=15 \mathrm{mT}$ ), however, the chlorophyll a and $\mathrm{b}$ ratios remained unchanged.

The ROS scavenging enzymes: superoxide dismutase (SOD), catalase (CAT), and peroxidases (POX) are the main protective agents against ROS formation SOD is the major enzyme involved in ROS detoxification, CAT is a key enzyme that eliminates $\mathrm{H}_{2} \mathrm{O}_{2}$, and POX catalyses the reaction of $\mathrm{H}_{2} \mathrm{O}_{2}$ degradation (Joun et al., 2012). Furthermore, guaiacol peroxidase (GPOX) [EC 1.11.1.7] is an enzyme of the peroxidase class that plays an important role in lignification, ethylene biosynthesis, or defence against pathogens and ROS (Mika and Lüthje, 2003). In the present paper, we have demonstrated that 130 -mT MFS has a beneficial influence on GPOX activity, which was manifested by a significant increase in GPOX activity by $44 \%$ in the bean leaves. Similarly, Atak $\boldsymbol{e t}$ al. (2007) observed a significant increase in GPOX activity in soybean (Glycine max L.) leaves exposed to 2.9-4.6 mT MFS for $2.2 \mathrm{~s}$ and $19.8 \mathrm{~s}$, but a better effect was obtained for the longer exposure time. Moreover, an electromagnetic field (275 $\mathrm{kV}$ ) contributed to a significant increase in GPOX activity in mustard (Brassica chinensis) leaves, although a weaker electromagnetic field $(33 \mathrm{kV})$ did not affect peroxidase significantly (Maziah et al., 2012). The increase in the GPOX activity that we noted in the bean (Phaseolus vulgaris L.) leaves may suggest increased potential of the plant defence system (Jouni et al., 2012). Furthermore, the studies carried out by Shabrangi et al. (2011) showed that magnetic field stimulation $(60 \mathrm{~Hz}, 3 \mathrm{mT}$ and $10 \mathrm{mT})$ increased the activity of other antioxidant enzymes, i.e. ascorbate peroxidase (APX) and superoxide dismutase (SOD) in maize (Zea mays) roots and shoots. SOD and CAT activity were also intensified in Glycine max (L.) seedlings due to the treatment with magnetic field (Çelik $\boldsymbol{e}$ al., 2009).

\section{CONCLUSION}

In conclusion, our results presented in this paper indicate that the 130-mT magnetic field stimulation promoted mitotic activity in meristematic cells in bean (Phaseolus vulgaris L.) roots. The development of the aboveground plant parts was slower, but at the control level. Similarly, the assimilation pigment content and GPOX activity in roots and leaves remained at the control level. However, there was a marked enhancement of GPOX activity in leaves after 130-mT MFS Our results might be useful to expand the general knowledge about the mechanism of the magnetic field action on plants. Currently, these phenomena are still unclear and require further research.

\section{REFERENCES}

AKINYELE, B.J., AKINKUNMI, O.C., ADEDAYO, K.D. 2012. Effect of electromagnetic field on the spoilage fungi of some selected edible fruits in southwestern, Nigeria. Journal of Microbiology, Biotechnology and Food Sciences, 2(2), 701-712.

AKSYONOV, S.I., BULYCHEV, A.A., AND GRUNINA, T. YU. 2001. Effects of ELF-EMF treatment on wheat seeds at different stages of germination and possible mechanisms of their origin. Electromagnetic Biology and Medicine, 20, 231-253. http://dx.doi.org/10.1081/JBC-100104146

ALKASSAB, A.T., AND ALBACH, D.C. 2014. Response of Mexican aster Cosmos bipinnatus and field mustard Sinapis arvensis to irrigation with magnetically treated water (MTW). Biological Agriculture \& Horticulture, 30(1), 62-72.

ATAK, Ç., ÇELIK, Ö., OLGUN, A,. AND ALIKAMANOĞLU, S. 2007. Effect of magnetic field on peroxidase activities of soybean tissue culture. Biotechnology \& Biotechnological Equipment, 21 (2), 166-171. http://dx.doi.org/10.1080/13102818.2007.10817438

BELYAVSKAYA, N.A. 2004. Biological effects due to weak magnetic field on plants. Advances in Space Research, 34, 1566-1574. http://dx.doi.org/10.1016/j.asr.2004.01.021 
BELYAVSKAYA, N.A., FOMICHEVA, V.M., GOVORUN, R.D., AND DANILOV, V.I. 1992. Structural-functional organization of the meristem cells of pea, lentil and flax roots in conditions of screening the geomagnetic field. Biophysics, 37, 657-666.

BILALIS, D.J., KATSENIOS, N., EFTHIMIADOU, A., KARKANIS, A., KHAH, E.M,. AND MITSIS, T. 2013. Magnetic field pre-sowing treatment as an organic friendly technique to promote plant growth and chemical elements accumulation in early stages of cotton. Australian Journal of Crop Science, 7(1), 46-50.

BRADFORD, M.M. 1976. A rapid and sensitive method for the quantitation of microgram quantities of protein utilizing the principle of protein-dye binding. Analytical Biochemistry, 72, 248-254. http://dx.doi.org/10.1006/abio.1976.9999

BRUINSMA, J. 1963. The quantitative analysis of chlorophylls a and $\mathrm{b}$ in plant extracts. Photochemistry and Photobiology (Chlor. Metabol. Sym.), 2, 241-249. http://dx.doi.org/10.1111/j.1751-1097.1963.tb08220.x

CAKMAK, T., CAKMAK, Z.E., DUMLUPINAR, R., AND TEKINAY, T. 2012 Analysis of apoplastic and symplastic antioxidant system in shallot leaves: impacts of weak static electric and magnetic field. Journal of Plant Physiology, 169, 1066-1073.

CÂMARA, C.R.S., URREA, C.A., AND SCHLEGEL, V. 2013. Pinto bean (Phaseolus vulgaris L.) as a functional food: implications on human health Agriculture, 3, 90-111. http://dx.doi.org/10.3390/agriculture3010090

ÇELIK, Ö., BÜYÜKUSLU, N., ATAK, Ç., AND RZAKOULIEVA, A. 2009 Effects of magnetic field on activity of superoxide dismutase and catalase in Glycine max (L.) Merr. roots. Polish Journal of Environmental Study, 18(2), 175182

CLARK, G. (red) 1981. Staining procedures - fourth edition. Wiliams and Wilkins Baltimore USA

DARDENIZ, A., TAYYAR, Ş., AND YALÇIN, S. 2006. Influence of lowfrequency electromagnetic field on the vegetative growth of grape cv. Uslu. Journal of Central European Agriculture, 7(3), 389-395.

DIJAK, M., SMITH, D.L., AND WILSON, T.J. 1986. Stimulation of direct embryogenesis from mesophyll protoplasts of Medicago sativa. Plant Cell Reports, 5, 468-470. http://dx.doi.org/10.1007/BF00269644

FOMICHEVA, V.M., GOVOROON, R.D., AND DANILOV, V.I. 1992 Proliferative activity and cell reproduction in meristems of seedling roots of pea, flax and lentil under conditions of screening of a geomagnetic field. Biofizika, 37, 745-749.

JOUNI, F.J., ABDOLMALEKI, P., AND GHANATI, F. 2012. Oxidative stress in broad bean (Vicia faba L.) induced by static magnetic field under natural radioactivity. Mutation Research, 741, 116-121.

KORNARZYŃSKI, K., PIETRUSZEWSKI, S., SEGIT, Z., SZWED-URBAŚ, K., AND ŁACEK, R. 2004. Preliminary investigation of the effect of static and alternating magnetic fields on growth speed of wheat germs. Acta Agrophysica $3(3), 521-528$.

LEBEDEV, S.I., BARANSKIY, P.I., LITVINENKO, L.G., AND SHIYAN, L.T. 1977. Barley growth in superweak magnetic field. Electronic Treatment of Materials, 3, 71-73 (in Russian).

LICHTENTHALER, H.K., AND WELLBURN, A.R. 1983. Determinations of total carotenoids and chlorophylls $\mathrm{a}$ and $\mathrm{b}$ of leaf extracts in different solvents. Biochemical Society. Transactions, 603, 591-592.

MAZIAH, M., OOI, B.B., TENGKU, M., AND SREERAMANAN, S. 2012 Effects of electromagnetic field of 33 and $275 \mathrm{kV}$ influences on physiological, biochemical and antioxidant system changes of leaf mustard (Brassica chinensis) African Journal of Biotechnology, 11(66), 13016-13029. http://dx.doi.org/10.5897/AJB11.1502

MIKA, A., AND LÜTHJE, S. 2003. Properties of guaiacol peroxidase activities isolated from corn root plasma membranes. Plant Physiology, 132, 1489-1498. http://dx.doi.org/10.1104/pp.103.020396

MUSZYŃSKI, S., GAGOS, M. AND PIETRUSZEWSKI, S. 2009. Short-term pre-germination exposure to ELF magnetic field does not influence seedling growth in durum wheat (Triticum durum). Polish Journal of Environmental Study, 18(6), 1065-1072.

NAGY, I.I., GEORGESCU, R., BĂLĂCEANU, L., AND GERMENE, S. 2005. Effects of pulsed variable magnetic fields over plant seeds. Romanian Journal of Biophysics, 15(1-4), 133-139.

NOVITSKAYA, G.V., TULINOVA, E.A., KOCHESHKOVA, T.K., AND NOVITSKY, Y.I. 2001. The effect of weak permanent magnetic field on cotyledon emergence and neutral lipid content in 5-day-old radish seedlings. In: Plant Under Environmental Stress. Publishing House of Peoples Friendship University of Russia Moscow 212-213 p.

PIETRUSZEWSKI, S., AND KANIA, K. 2010. Effect of magnetic field on germination and yield of wheat. International Agrophysics, 24, 297-302.

PIETRUSZEWSKI, S., KORNARZYŃSKI, K,. AND ŁACEK, R. 2001. Germination of wheat grain in an alternating magnetic field. International Agrophysics, 15, 269-271.

RĂCUCIU, M. 2011. $50 \mathrm{~Hz}$ frequency magnetic field effects on mitotic activity in the maize root. Romanian Journal of Biophysics, 21(1), 53-62.

RĂCUCIU, M., CREANGĂ, D., AND HORGA, I. 2008. Plant growth under static magnetic field influence. Romanian Journal of Biophysics, 53(1-2), 353
359

SHABRANGI, A., AND MAJD, A. 2009. Effect of magnetic fields on growth and antioxidant systems in agricultural plants. Progress in Electromagnetics Research Symposium, Beijing China 1142-1147 p.

SHABRANGI, A., MAJD, A., AND SHEIDAI, M. 2011. Effects of extremely low frequency electromagnetic fields on growth, cytogenetic, protein content and antioxidant system of Zea mays L. African Journal of Biotechnology, 10(46), 9362-9369.

VASHISTH, A., AND NAGARAJAN, S. 2009. Effect on germination and early growth characteristics in sunflower (Helianthus annuus L.) seeds exposed to static magnetic field. Journal of Plant Physiology, 167, 149-156.

VELIKOVA, V., YORDANOV, I., AND EDREVA, A. 2000. Oxidative stress and some antioxidant systems in acid rain-treated bean plants. Protective role of exogenous polyamines. Plant Science, 151, 59-66.

YAYCILI, O., AND ALIKAMANOGLU, S. 2005. The effect of magnetic field on Paulownia tissue cultures. Plant Cell, Tissue and Organ Culture, 83, 109-114. http://dx.doi.org/10.1007/s11240-005-4852-0 